\title{
Research on the Reform of University Teaching Management in the Perspective of Innovation Talents Cultivation
}

\author{
$\operatorname{Xin~} \mathbf{L i}^{1}$ \\ ${ }^{1}$ Academic Affairs Office \\ North China Electric Power University \\ Baoding, China
}

\author{
Ming-yao Chen ${ }^{2}$ \\ ${ }^{2}$ Industrial and Commericial College, \\ Hebei University, \\ Baoding, China
}

\begin{abstract}
The teaching management work as an important part of the school teaching, is to maintain the normal teaching order, improve teaching efficiency and quality of the important guarantee. To study the mechanism of university teaching management is very important for the innovation of university teaching management and the cultivation of innovative talents.
\end{abstract}

Keywords: teaching management; innovation talents cultivation; education reform;

\section{INTRODUCTION}

Innovation is the progress of human civilization and an important driving force, greatly contributed to the progress of human civilization. After higher education reform in the 21st century, the world spontaneously to cultivate innovative talent as one of the main goals of education reform. The key to innovation lies on the talent, talent depends on education, and therefore cultivation of innovative talents to become China's education, especially higher education, can not shirk responsibility. Ultivate the innovative talents plays a pivotal role in the economic development and social progress in the 21st century, it is based on the innovation of knowledge and technology, but how to effectively protect the cultivation of innovative talent, is the education scholars' research hot issue, is also the theoretical and practical circles unremitting pursuit. Especially in the construction of innovation-oriented countries in the larger context, all the more highly desirable. Settled on personnel training, it relates to the management of the training process, the core is teaching management, teaching quality management directly affect the overall level of teaching and innovative talents. Teaching management with the training objectives, training mode, reform of the teaching process, it is a dynamic process of development. There is no end to the management reform, and so is the teaching management, which always innovate unceasingly under certain social environment. Especially in the knowledge economy society, the rapid growth of knowledge, the inevitable need of teaching plan, teaching content, curriculum setting are constantly updated development, which requires the teaching management should be changed, in order to guarantee the teaching goal efficiently. Therefore, to seize the university's teaching management reform and innovation as the core, and learn the experience of our country in the past, the reform of teaching management, put forward more effective reform measures according to the reform of teaching management research.

\section{The situation of teaching management in universities and colleges}

\subsection{Contents of teaching management}

The university teaching management is a kind of special form of management activity and a special form of the university management. It is a subset of human management activity. Therefore, the university teaching management not only has the general management common, but also has its own particularity.

A generalization of the teaching management, is to study the educational administrative organizations at all levels of schools and other institutions of education teaching organization, management and guidance from the macro level, in the narrow sense from the school perspective, it is teaching management as school internal management, most current research from the school level are analyzed. Teaching management in universities and colleges, which is managers follow management rules and teaching law, use its influence education and scientific management principles, methods, and through a series of management practices and modern management tools, scientific planning, organization, coordination, control, the use of an internal system of teaching human, financial and material resources, time, information, and other factors to ensure that the teaching work, the orderly and efficient operation of the implementation, in order to achieve a predetermined target cultivate talent all-round development of moral, intellectual, physical. The basic task of teaching management including teaching and management rules, improve teaching management, improve teaching management level; the establishment of a stable teaching order, to ensure the normal 
operation of teaching; research and implement education reform; efforts to mobilize teachers and students in teaching and learning initiative. The process management includes the organization and the implementation of the teaching process, the control of teaching quality and its working system and procedure.

\subsection{Problems of teaching management}

\subsubsection{Undeveloped teaching management system}

The so-called system is refers to the state organs, enterprises and institutions, institutional settings, mutual relationship and division of responsibilities and rights of the system, the teaching management system is the basic organization system of teaching management mechanism, the management of the main powers and their relationships. At present, teaching management of colleges and universities is mainly carried out through a series of rules and regulations, although the rules and regulations in ensuring the teaching activities orderly carried out to a certain positive role, but has shown more unscientific, unreasonable management mode. Firstly, this is only a superficial form of management, it can only on surface behavior of teachers and students in the teaching activities of some specification, constraints and limitations, not in the teaching quality and talent culture quality guarantee; secondly, it is not conducive to the reform of teaching method and the teaching organization form. Some scholars believe that, if we want to cultivate innovative talents, we must be flexible teaching methods and teaching organization form, especially to carry out social practice and some extracurricular innovation activities, training and cultivation of students' innovative quality, too many rules to bound students brothers, it will not be able to carry out teaching reform; finally, the enthusiasm of the teachers and students easily lead to adverse consequences, some colleges and universities teaching management simple, make some strict, rigorous regulations and penalties, not only can not mobilize teachers and students to work with enthusiasm for learning, but many teachers and students caused resentment and strong dissatisfaction.

2.2.2 The impact of the traditional national culture of negative factors on the Teaching Management

Any nation has its own cultural traditions, different values, after thousands of years of subtle and the formation, it have a major impact on the creative teaching management activities. China has a long history of closed-door policy, leaving many ban solid ideological and cultural legacy. Traditional culture is not coming to the fore and to encourage the creation of moderation, contentment ingrained ideas. So the Chinese more conservative, stability, obedient, obedient. As a result, many colleges and universities play teaching managers like to peer behavior as a model specification. Since the $1970 \mathrm{~s}$, some key university appeared both in teaching and scientific research center, requires teachers to do a good job in teaching should also be engaged in sci- entific research, , to the majority of students creativity is not required, resulting in many students rest on its laurels, conservative, and conformity.

\subsubsection{Specialty unified directory management}

University personnel training, mainly through professional settings and develop appropriate teaching programs and curriculum system to complete, professional set up our current colleges and universities primarily through the publication of professional directories, not be forced to implement a unified management. 1980 of a total of more than 1300 kinds of professional colleges and universities, but now just over 200 kinds. When the division of labor too small, specialized narrow, difficult to cultivate master talent. The university graduates to find and create something good at thinking quickly changing environment and accurate judgment, we must have deep knowledge and broad knowledge base. When professional caliber too broad, it is difficult for students to delve deeper into their professionals.

\section{The relationship between innovation talent cultiva- tion and college teaching management}

If teaching management departments to meet innovative talents to teaching management reform of the requirements, it is necessary to recognize the importance of innovation ideologically talents, we should always focus on "student-centered" and "student-centered" concept to work. Teaching management is an important part of school education, teaching management innovation is the key to cultivating innovative talents.

\subsection{Innovative teaching management}

Firstly, innovation management ideas, from the point of view of academic and innovation, change the management pattern of the university; secondly, innovation management system and organization; thirdly, innovation management technology and means; fourthly, cultural innovation in teaching management, such as cultural background, cultural atmosphere, cultural values; lastly, innovative teaching management culture.

\subsection{Innovative talent}

Teaching management, innovation management personnel training that is teaching how to provide a high quality environment and service personnel training, which reads as follows: firstly, build innovative concept system; secondly, cultivating mechanism of innovation, including the management mechanism and dynamic mechanism; thirdly, cultivating innovative talents of academic strength, including teaching techniques, teachers, curriculum and research; and environmental construction; lastly, innovative talents, such as the regulatory environment, learning and counseling environment, living environment. 


\section{Improving the cultivation of innovative talents in teaching management}

\subsection{Innovative teaching management ideas}

Traditional teaching management should be on teachers, teaching materials, classroom as the center of a closed mode integrated into information management mode, in order to cultivate innovative personnel to meet the social development needs of the compound.

Improvement and innovation management system, combined with the characteristics of students, knowledge structure, and the objectives and requirements, detailed organization and implementation of measures; when setting teaching, optimize resources, individualized study, develop their ability to innovate; in implementation it should reflect the new concept of teaching management, personnel training, follow the human spirit, and enhance management efficiency.

\subsection{Carry out practice and exploration, create an en- vironment conducive to innovation and personnel training mechanism}

Teaching managers to thoroughly realistic and development direction of higher education, to fully tap the advantages of resources, and gradually establish a modern education and management concepts, and create favorable Creative Talent campus atmosphere and incentives. First, in order to discipline "platform courses" basis, planning disciplines basic courses and professional courses, reflecting the coverage of the disciplines of basic knowledge, comprehensive professional courses and study characteristics, and through the syllabus of the course content and system optimization. Second, the rich curriculum resources, student enrollment increased flexibility, emphasizing compulsory credits instead of required courses, students under the guidance of teachers, based on professional, interest free elective for their custom-made "individual learning plans." Third, implement curriculum integration and restructuring, strengthening and integration of cross-disciplinary and achieve wide caliber culture. Third, the integration and re- structuring of the curriculum, strengthening the discipline intersection and integration, to achieve wide caliber training.

\section{Conclusion}

Teaching Management is a comprehensive, highly academic, direct services to the management of personnel training, and innovative talents of university teaching management has put forward higher requirements. The traditional teaching management should be used to it, not just to do methods and means of transformation, the more important is to raise awareness from the thoughts and ideas.

It includes understanding what is innovation talents, what characteristics innovative talents has, what kind of relationship between the teaching management reform, what are the factors based on the innovative talent training of teaching management should have, how to college teaching management reform based on the innovative talent training etc. This all need to have a clear understanding. Therefore, universities should innovate teaching management idea, innovating teaching method, abundant curriculum resources, provide opportunities for the practice of students, improve them the creative thinking by practice.

\section{References}

[1] zhao qian. Teaching management in the innovative talents perspective $[\mathrm{J}]$, China education innovation herald, 2012 (10).pp 230.

[2] Zhu Hui. The Countermeasures Research for Teaching Management Innovation from the Perspective of Cultivating Innovative Talents by High Education [D]. Nanjing University of Aeronautics and Astronautics, 2008.

[3] Jin Lu. Cultivation of innovative talents and reform of teaching management $[\mathrm{J}]$.Higher education development and evaluation, 2008 (6).pp34-38.

[4] Zhao Xingjun, Yao Ziyan. On Construction and Creative Talent Moral Education Management System [J]. China Educational Technology Equipment, 2011 (14).pp124-125. 